\title{
The Turkish Version of Reliability and Validity of Nine Item-European Heart Failure Self-Care Behaviour Scale
}

\section{Dokuz Maddelik Avrupa Kalp Yetmezliği Özbakım Ölçeği'nin Türkçe Geçerlilik ve Güvenilirliği}

\author{
Esra Yıldız', Behice Erci \\ ${ }^{1}$ Atatürk Üniversitesi Sağllk Bilimleri Fakültesi, Hemsirelik Bölümü, Erzurum; ${ }^{2}$ İönü Üniversitesi Sağllk Bilimleri Fakültesi, \\ Hemşirelik Bölümü, Malatya, Türkiye
}

\begin{abstract}
Aim: The aim of this study was to develop and assess the validity and the Turkish version of reliability of Nine Item European Heart Failure Self-Care Behaviour Scale (EHFScB Scale-9).

Material and Method: This methodological study was conducted with 123 heart failure (HF) patients whose mean age was $61.82 \pm 11.39$ years. The language adaptation, validity assessment and Cronbach's alpha coefficients and the item-total correlation were examined.
\end{abstract}

Results: Factor analysis of the scale found a KMO index of 0.757 , a Bartlett'ssphericity of $X^{2}=384.870, d f=36$, and $p=0.000$. Two factors explain $56.5 \%$ of the total variance. Internal consistency reliability of the whole questionnaire was 0.820 . All items of factor loadings were above 0.40 and factor loadings of the items ranged from $0.511-0.817$ in the scales. Item-total correlations were 0.381 and 0.639 for the two dimensions.

Conclusion: The Turkish version of the EHFSCB-9 scale is a valid, reliable tool, which can be used to measure HF self-care behavior.

Key words: heart failure; self-care; validity; reliability

\section{ÖZET}

Amaç: Bu çalıșma 9 maddelik Avrupa Kalp Yetmezliği Özbakım Davranıșları ölçeğinin Türkçe geçerlilik ve güvenilirliğinin test edilmesi amacı ile yapıldı (AKYÖB-9).

Materyal ve Metot: Metodolojik olan bu çalıșma yaș ortalaması 61,82 11 ,39 olan kalp yetmezliği tanısı almıș 123 kalp hastası ile yapıldı. Dil adaptasyonu geçerlilik değerlendirmesi Cronbach's alfa iç tutarlıık katsayısı ve madde toplam korelasyonu hesaplandı.

Bulgular: Yapılan factor analizinde $K M O$ indeks değeri 0,757, Bartlett'sphericityX² değeri 384,870, df: 36, p: 0,000. Cronbach's alfa değeri 0,820 olduğu saptandı. Ölçeğin iki faktörü toplam varyansın \%56,5'ini açıklamaktadır. Ölçeğin tamamı

Esra Yildız, Atatürk Üniversitesi Să̆lık Bilimleri Fakültesi Erzurum - Türkive, Tel.04422315697Email.esrazengin82@gmail.com

Geliş Tarihi: 13.04.2017 • Kabul Tarihi: 11.12.2017 için iç tutarlılık güvenilirliği 0,820'dir. Ölçeğin tüm factor yükleri 0,40'ın üstünde ve maddelerin factor yükleri 0,511-0,817 arasında değișiyordu. Madde-toplam korelasyonları iki boyut için 0,381 ve 0,639'dı.

Sonuç: AKYÖB-9 ölçeğinin Türkçe versiyonu kalp yetmezlikli hastaların özbakım davranıșlarını ölçmede kullanılabilecek güvenilir bir araçtır.

Anahtar kelimeler: kalpyetmezliği; özbakım; geçerlilik; güvenilirlik

\section{Introduction}

The current heart failure (HF) epidemia is one of the most serious and challenging public health problems. In recent years, there has been an increase in both the number of patients diagnosed with heart failure and the related hospitalizations, the results of which have led to an increased economic burden on the healthcare system ${ }^{1}$. Among chronic diseases, HF ranks high in terms of prevalence, incidence, and cost. It often requires immediate aid and hospital treatment ${ }^{2}$. To enable the provision of better healthcare, the effects of HF on self-care must be examined ${ }^{3}$. Two HF-specific scales are currently available to measure self-care behaviors: The Self-Care of Heart Failure Index (SCHFI) and The European Heart Failure Self-care Behavior Scale (EHFScBS-12-9) ${ }^{4-6}$.

Gonzales et al. found in their studies conducted on patients with heart failure in the Netherlands, Italy and Sweden that the patients' self-care behaviors changed over time ${ }^{7}$.

Camerun et al. found that the severity of heart failure, time of diagnosis, and patients' depression and mental status affected their self-care ability ${ }^{8}$. 
Self-care behaviors for HF include using medications, as prescribed by healthcare professionals, restricting salt and fluid intake, limiting activities and making decisions about treatment and care depending on symptoms and indications of worsening illness.

Patient education and support for patients with heart failure (HF) to improve self-care behaviors. The effectiveness of these programs is often evaluated based on their impact on readmission, costs, and quality of life. Hospitalization rates, the need for emergency room visits, and decreased quality of life due to heart failure can be improved by better self-care. In contrast, the inability of HF patients to maintain a sufficient level of self-care increases the frequency of their hospitalizations ${ }^{9,10}$. To enhance self-care in HF patients and to assess the effectiveness of related interventions, a measurement tool is needed ${ }^{5}$. The European Heart Failure Self-care Behavior was developed to be this tool, and it has proved to be an important, valid, and reliable measurement for HF patients ${ }^{5,11}$. The EHFScBS-9 is the short version of the EHFScB scale and has been translated into English, Brazilian Portuguese, Swedish, Chinese, Italian, German, Finnish, Spanish, Greek, Dutch, Polish and Japanese languages ${ }^{11-19}$. A study using a scale to analyze the self-care behaviors of patients with heart failure in 15 countries showed that most patients took their medicine but did a low level of exercise, and did not regularly or daily monitor their weight; Austria was found to have the lowest rate of weight monitoring. In addition, the rate of being vaccinated against flu and limiting salt consumption were found to differ by country ${ }^{19}$. To date, there is no Turkish version of the EHFScBS-9 available. This study aimed to evaluate the validity and reliability of a Turkish version of the EHFScBS-9.

\section{Material and Method}

\section{Translation}

The initial step in the adaptation of a scale is to analyze the validity of the language by using Davis method. The main criteria used for language adaptation and translation of a measurement tool that has been developed in a foreign language are that the adapted tool has minimal differences in conceptualization and expression from the original tool and that the tool is made meaningful in the target language without making major changes to the scale's composition ${ }^{20}$. To achieve these criteria, we consulted a linguist for back translation. First, the EHFScBS-9 (English version) was translated into Turkish. Used two different translation centers working independently. Then, two researchers created the Turkish text by using the the most appropriate expression for all item and changing some words and sentences to make the meaning and conceptual equivalence more accurate. Next, the scale was translated into English using back translation by a linguist well versed in English and Turkish, and then, it was compared to its original form. To achieve linguistic validity, inappropriate expressions were revised.

\section{Content Validity}

To test the scales clarity and content, the translated version presented a panel of seven experts. The author was informed about the measures and concepts.

This multidisciplinary panel was the subject of research in cardiology by two public health nursing, two cardiologists and three medical nursing specialists. Panel members were asked to rate the content of the latest version of EHFSCBS-9 when compared to the original instrument.

Experts asked for each items of scales EHFScBS-9 using a 4-point Likert Scale: 4=very available, 3=available but needs little improvement, $2=$ your item needs too much revision, $1=$ not avaliable.

When scales and content validity index (CVI) are evaluated, the items values were found to be between 0.85 and 1.00 . The Content validity Index calculated for all items of EHFScBS-9 Turkish version was found to be 0.93 .

In addition to the EHFScBS-9, the present study administered a 3 -question survey asking patients their age, duration of $\mathrm{HF}$ and gender.

The study was conducted between June and September of 2013 in the city of Erzurum in eastern Turkey, using patients recruited from the cardiology polyclinics of a university hospital. The data were collected on Mondays by researchers using the self-report method. The interviews were generally completed in 10-15 minutes.

The data were evaluated using SPSS 20.0 and Amos 21.0 software.

\section{Reliability}

To test the internal consistency of the scale, Cronbach's alpha coefficients and the item-total correlation were examined. 


\section{Validity}

While to test its structural validity, exploratory factor analysis was used, followed by confirmatory factor analysis.

Bartlett'sphericity test was used to determine whether the correlation matrix was a unit matrix and to decide, depending on its results, the appropriateness of using a factor model. To test sample-size sufficiency, the Kaiser-Meyer-Olkin (KMO) Index was used. For comparison of the correlations between items and the total score, Pearson moment correlation was used. The threshold of statistical significance was $\mathrm{p}<0.05$.

\section{Results}

The mean age of the participants was $61.82 \pm 11.39$ years. The mean time since diagnosis of HF was $6.38 \pm 5.84$ years. Of the 123 participants, 53 were female (43.1\%) and 70 were male (56.9\%). Confirmatory factor analysis was used to evaluate the structural validity of the EHFScBS-9 scale. The Cronbach's alpha coefficient was 0.820 for all scale items, while for items in the first subdimension, it was 0.783 , and for items in the second subdimension, it was 0.728 .

\section{Analyzing Items and Internal Consistency}

To determine the EHFScBS-9 scale's reliability, its items were analyzed. First, exploratory factor analysis was performed to examine the factor structure of the nine-item scale, including how many factors composed the scale and the distribution of items under these factors. Which items are weighted by which factor and their weight levels can be found under the factors, to which Varimax rotation was applied.

The KMO Index was used to determine the sample sufficiency value. Table 1 shows the KMO coefficient, which was 0.757 , and the results of the Bartlett's sphericity test, which were $\mathrm{X}^{2}=384.87, \mathrm{df}=36$, and $\mathrm{p}=0.000$, all of which indicatethe appropriateness of the data set for factor analysis. As Table 1 shows, the KMO coefficient was $>0.70$, and the sphericity test resulted in $\mathrm{p}<0.05$, an indication that the data set was appropriate for factor analysis. The KMO values signify the adequacy of the sample. The results of the exploratory factor analysis and the principle components analysis indicated that the scale has a two factor-structure, where the two-factors explained a total of $56.54 \%$ of the total variance.
According to Table 2, of the 9 items weighted under the 2 factors, items 2, 3, 4, 6, and 9 are weighted under the first factor, consulting behavior, and items $1,5,7$, and 8 are weighted under the second factor, adherence to regimen.

According to Table 3, the item-total correlation values vary between 0.366 and 0.639 . In the Turkish version, the items' Cronbach alpha coefficient values vary between 0.786 and 0.818 .

Table 1. KMO coefficient and the results of Bartlett's sphericity test

\begin{tabular}{llc}
\hline KM0 Sample Sufficiency coefficient & & 0.757 \\
Bartlett Sphericity Test & Chi-square & 384.870 \\
& $\begin{array}{l}\text { Degrees of } \\
\text { Freedom }\end{array}$ & 36 \\
& $\mathrm{p}$ & 0.000 \\
\hline
\end{tabular}

KMO: Kaiser-Meyer-0lkin

Table 2. Items' factor loadings and components

\begin{tabular}{|c|c|c|c|}
\hline & & \multicolumn{2}{|c|}{ Component } \\
\hline & & 1 & 2 \\
\hline Item 2 & & 0.799 & \\
\hline Item 4 & & 0.726 & \\
\hline Item 9 & & 0.692 & \\
\hline Item 3 & & 0.688 & \\
\hline Item 6 & & 0.637 & \\
\hline Item 8 & & & 0.817 \\
\hline Item 7 & & & 0.803 \\
\hline Item 5 & & & 0.689 \\
\hline Item 1 & & & 0.511 \\
\hline$\%$ of Variance & & $30.58 \%$ & $25.95 \%$ \\
\hline \multicolumn{4}{|c|}{$\begin{array}{l}\text { Extraction Method: Principal Component Analysis. } \\
\text { Rotation Method: Varimax with Kaiser Normalization. } \\
\text { a. Rotation converged in } 3 \text { iterations. }\end{array}$} \\
\hline \multicolumn{4}{|c|}{$\begin{array}{l}\text { Table 3. Items' Corrected Item-Total Correlation and Cronbach's alpha o } \\
\text { EHFSCBS } 9\end{array}$} \\
\hline & $\begin{array}{l}\text { Corrected Item } \\
\text { Total Correlation }\end{array}$ & $\begin{array}{r}\text { Cronb } \\
\text { it }\end{array}$ & $\begin{array}{l}\text { alpha when } \\
\text { deleted }\end{array}$ \\
\hline Item 1 & 0.480 & & 307 \\
\hline Item 2 & 0.580 & & 794 \\
\hline Item 3 & 0.615 & & 790 \\
\hline Item 4 & 0.639 & & 786 \\
\hline Item 5 & 0.522 & & 801 \\
\hline Item 6 & 0.521 & & 801 \\
\hline Item 7 & 0.563 & & 796 \\
\hline Item 8 & 0.381 & & 817 \\
\hline Item 9 & 0.366 & & 818 \\
\hline
\end{tabular}




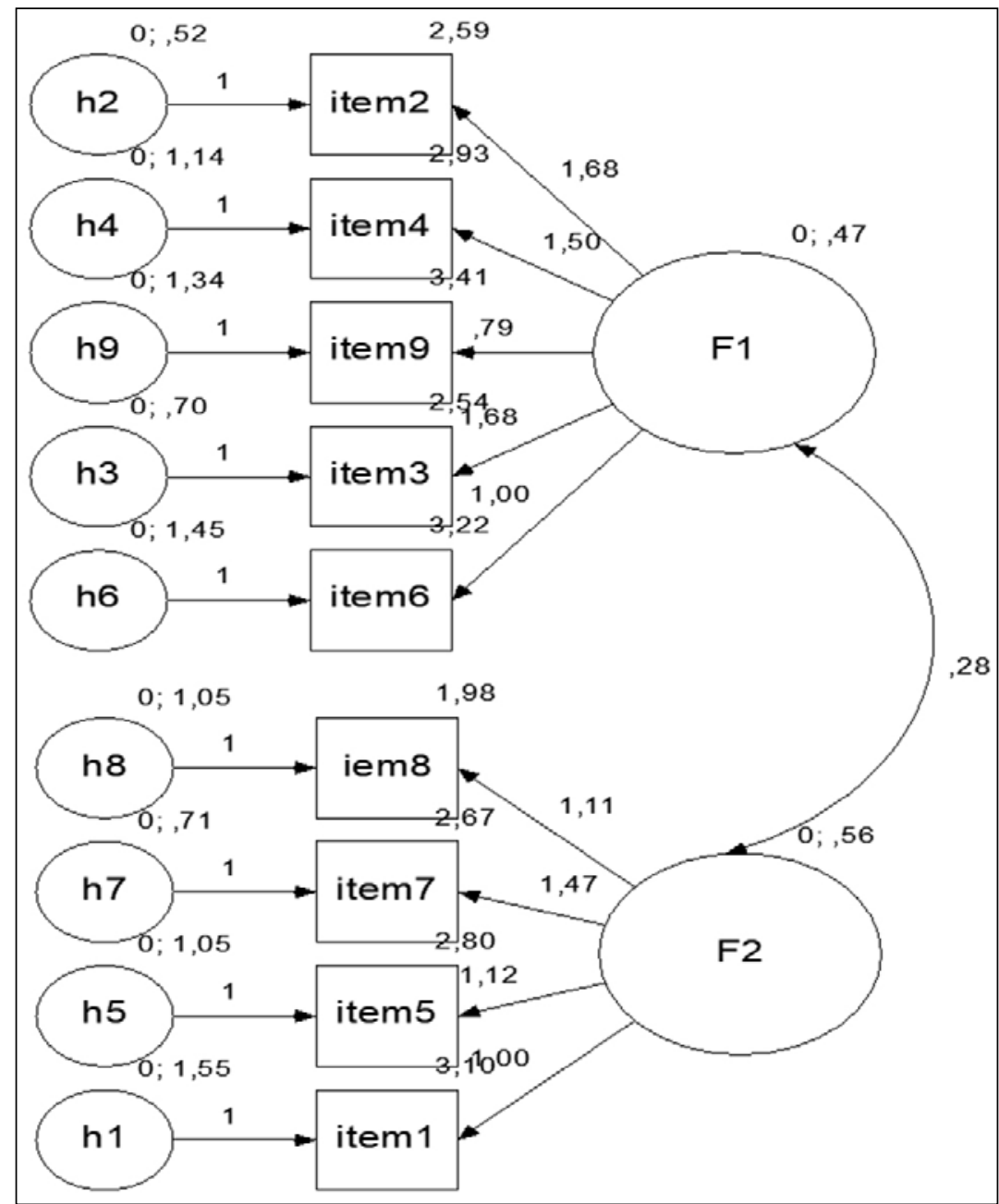

Figure 1. Path of The Turkish Version of EHFSCBS-9.

To test the concordance of the model that was composed in this way, which is diagrammed in Figure 1, confirmatory factor analysis was used. As can be seen in Table 4, the goodness of fit indices for the Turkish version of the EHFScBS-9 had aChi-square value of 65.598. As a finding $<3$ indicates a good concordance, theComparative Fit Index (CFI) value of 0.92 qualifies as good concordance, as does the Root Mean Square Error of Approximation (RMSEA) value of 0.06 .
Based on these findings, this model was found to have good concordance $e^{21-23}$.

\section{Discussion}

Due to population aging and treatments that allow patients to live longer, the frequency of HF is increasing in the member countries of the European Society of Cardiology, of which Turkey is one ${ }^{24}$. In addition, HF

Table 4. Goodness of fit indices for the Turkish Version of EHFSCBS-9

\begin{tabular}{llccccc}
\hline Chi-square & $s d$ & $p$ & Chi-square/sd & GFI & CFI & RMSEA \\
\hline 65.598 & 26 & 0.000 & 2.523 & 0.91 & 0.923 & 0.06 \\
\hline
\end{tabular}

SD: Standard Deviation; CFI: Comparative Fit Index; GFI: Goodness of Fit Index; RMSEA: Root Mean Square Error of Approximation 
is one of the most serious, difficult public health problems worldwide, with increasing mortality, morbidity, and hospitalizations and decreasing self-care abilities, all of which cause increased economic burden on the healthcare system. Self-care, in particular, is effective in treating HF patients' symptoms and complications and in maintaining their quality of life $\mathrm{e}^{25}$.

The present study analyzed the validity and reliability of a Turkish form of the EHFScBS-9, first developed by Jaarsma et al. in 2003 as the EHFScBS, before being reduced to a nine-item scale, the EHFScBS-9, in 2009. The scale consists of two factors: consulting behavior and adherence to regimen 5 .

Exploratory factor analysis was used to establish the scale's construct validity. Results of this analysis showed a KMO coefficient of 0.757 and Bartlett's test results of $\mathrm{X}^{2}=384.87, \mathrm{df}=36$, and $\mathrm{p}=0.000$, all of which indicate that the sample was adequate for exploratory factor analysis. The scale was determined to have two subdimensions, like the original scales. Allscale items fit into one or the other of the two dimensions, and all item factor loadings had values of 0.30 or greater ${ }^{22}$. The Cronbach's alpha coefficient of all scale items was 0.820 , a result equivalent to the 0.80 alpha value of the original scale. For items in the first subdimension, the alpha coefficient was 0.783 , and for items in the second subdimension, it was 0.728 . These results indicate that the scale is sufficient to evaluate the self-care of HF patients. The reliability coefficient for the entire scale was found to be high. Astudy by Koeberich et al. ${ }^{12}$ on German HF patients found the Cronbach's alpha coefficient for the EHFScB-9 scale to be 0.71. Furthermore, aUS study by Lee et al. ${ }^{13}$ determined the Cronbach's alpha coefficient to 0.80 , whileLambrinou et al. ${ }^{16}$ found it to be 0.66 for the Greek version.

The two factors explain $56.5 \%$ of the total variance. The total item correlations of the scale were at a high level, having a score greater than 0.30 (0.366 to 0.639 ). Jaarsma et al. $^{5}$ reported that only the item "I take my medication as prescribed" showed a correlation value lower than 0.30 in the original scale; other total item correlation values were higher than 0.30 , as in the present study. Köberich et al. ${ }^{12}$ found the total item correlations to range between 0.09 and 0.63 for the German version of the scale and the total item correlation values of items 8 and 9 to be lower than 0.20 (item 8:0.13; item 9:0.09). Lee et al. ${ }^{13}$ reported the total item correlation scores to range between 0.25 and 0.65 in the
USA. It can be concluded based on these results that all items show a high reliability for the Turkish version of the scale. In confirmation of the two-factor model of the scale, the principal component analysis using Varimax rotation showed that two factors do in fact lie within the scale. The present study determined that the factor structure of the original scale, which was composed of two factors, was appropriate for Turkish cultural values. Surprisingly, the items in both dimensions were the same as those in the study by Jaarsma et al. ${ }^{5}$, except for the ninth item, namely, "I exercise regularly." This may indicate that the concepts of exercise and its regularity may be perceived differently in Turkish society than in European society; that is, the exercise may be less strenuous in Turkish society

This study's examination of the validity and reliability of a Turkish version of the EHFScB-9 scale indicated that healthcare professionals can use the scale for HF patients. Its Chi-square value of below 3 indicates good concordance ${ }^{23}$, as do its CFI value of 0.92 , GFI value of 0.91 and its RMSEA value of 0.06 . A RMSA value equal to or lower than 0.08 indicates a good concordance. CFI and GFI values equal to or higher than 0.90 indicate concordance ${ }^{26}$. Jaarsma et al. ${ }^{6}$ found higher concordance index values in the original scale than those for the EHFScB-12, the former of which were similar to the findings of the present study. Lee et al. ${ }^{13}$ and Vellone et al. ${ }^{11}$ also reported findings similar to the concordance index findings of the present study.

As the results of the present study show that the EHFScBS-9 has good psychometric properties of validity, reliability, and precision, it can be recommended for use in measuring self-carebehavior in clinical practice, homecare, phone and web monitoring, and research. The EHFScB scale is very important because it provides standardized data patient's behaviour related heart failure self-care behaviour regarding adult's health.

In addition, similar HF scales that have been developed in foreign languages should be tested to evaluate their appropriateness for Turkish cultural values, as these adaptation studies can contribute to the HF literature.

\section{Acknowledgements}

We are grateful to the patients who participated in the study and to the staff members of the cardiology polyclinics. 


\section{References}

1. Kosiborod M, Krumholz H. Epidemiology of Heart Failure In: William T. Abraham HK, ed. Heart Failure A Practical Approach To Treatment 1 ed. İstanbul: AND 2007:9.

2. Dickson VV, Knafl GJ, Wald J, Riegel B. Racial Differences in Clinical Treatment and Self Care Behaviors of Adults With Chronic Heart Failure. J Am Heart Assoc 2015;4(4):1-13.

3. Heo S, Lennie TA, Okoli C, Moser DK. Quality of life in patients with heart failure: ask the patients. Heart Lung 2009;38(2):100-8.

4. Riegel B, Lee CS, Dickson VV, Carlson B. An update on the selfcare of heart failure index. J Cardiovasc Nurs 2009;24(6):48597.

5. Jaarsma T, Årestedt KF, Mårtensson J, Dracup K, Strömberg A. The European Heart Failure Self-care Behaviour scale revised into a nine-item scale (EHFScB-9): a reliable and valid international instrument. Eur J Cardiovasc Nurs 2009;11(1):99-105.

6. Jaarsma T, Strömberg A, Mårtensson J, Dracup K. Development and testing of the European Heart Failure Self-Care Behaviour Scale. Eur J Cardiovasc Nurs 2003;5(3):363-70.

7. Cameron J, Worrall-Carter L, Page K, Riegel B, Lo SK, Stewart S. Does cognitive impairment predict poor self care in patients with heart failure? Eur J Heart Fail 2010;12(5):508-15.

8. González B, Lupón J, Parajón T, Urrutia A, Herreros J, Valle V. Use of the European Heart Failure Self-care Behaviour Scale (EHFScBS) in a heart failure unit in Spain. Rev Esp Cardiol 2006;59(2):166-70.

9. Riegel B, Moser DK, Anker SD, et al. State of the science promoting self-care in persons with heart failure: a scientific statement from the American Heart Association. Circulation 2009;120(12):1141-63.

10. Badır A. Chronic Heart Failure and Care In: Durna A, ed. Chronic Diseases and Care İstanbul: Nobel Medical Bookstore 2012: p.147-59.

11. Vellone E, Jaarsma T, Strömberg A, et al. The European Heart Failure Self-care Behaviour Scale: new insights into factorial structure, reliability, precision and scoring procedure. Patient Educ Couns 2014;94(1):97-102.

12. Köberich S, Glattacker M, Jaarsma T, Lohrmann C, Dassen T. Validity and reliability of the German version of the 9-item European Heart Failure Self-care Behaviour Scale. Eur J Cardiovasc Nurs 2013;12(2):150-8.

13. Lee CS, Lyons KS, Gelow JM, et al. Validity and reliability of the European Heart Failure Self-care Behavior Scale among adults from the United States with symptomatic heart failure. Eur J Cardiovasc Nurs 2013;12(2):214-8.
14. Pulignano G, Del Sindaco D, Minardi G, et al. Translation and validation of the Italian version of the European Heart Failure Self-care Behaviour Scale. J Cardiovasc Med 2010;11(7):493-8.

15. Doris S, Lee DT, Thompson DR, Jaarsma T, Woo J, Leung EM. Psychometric properties of the Chinese version of the European Heart Failure Self-care Behaviour Scale. Int J Nurs Stud 2011;48(4):458-67.

16. Lambrinou E, Kalogirou F, Lamnisos D, et al. The Greek version of the 9-item European heart failure self-care behaviour scale: A multidimensional or a uni-dimensional scale? Heart Lung 2014;43(6):494-9.

17. Uchmanowicz I, Łoboz-Rudnicka M, Jaarsma T, ŁobozGrudzień K. Cross-cultural adaptation and reliability testing of Polish adaptation of the European Heart Failure Selfcare Behavior Scale (EHFScBS). Patient Prefer Adherence 2014;8:1521-6.

18. Sedlar N, Lainscak M, Mårtensson J, Strömberg A, Jaarsma T, Farkas J. Factors related to self-care behaviours in heart failure: A systematic review of European Heart Failure Self-Care Behaviour Scale studies. Eur J Cardiovasc Nurs 2017;16(4):272-82.

19. Jaarsma T, Strömberg A, Gal TB, et al. Comparison of self-care behaviors of heart failure patients in 15 countries worldwide. Patient Educ Couns 2013;92(1):114-20.

20. Polit DF, Beck CT. Essentials of nursing research: Appraising evidence for nursing practice: Lippincott Williams \& Wilkins 2013.

21. Sun J. Assessing goodness of fit in confirmatory factor analysis. Meas Eval Couns Dev 2005;37(4):240-56.

22. Burns N, Grove SK. Understanding nursing research: Building an evidence-based practice: Elsevier Health Sciences 2010.

23. Özdamar K. Paket programlar ile istatistiksel veri analizi (Statistical data analysis with package programs). Eskişehir, Turkey: Kaan Publications 2004.

24. Çavuşoğlu Y, Seferovic PM, Mebazaa A. Heart Failure and Importance of Collaboration of Professional Organizations: The Role of the Heart Failure Association of the European Society of Cardiology and Its Committee on National Heart Failure Societies. Anatol J Cardiol 2015;15(4):344-5.

25. Evangelista LS, Shinnick MA. What do we know about adherence and self-care? J Cardiovasc Nurs 2008;23(3):250-7.

26. Esin N. Veri Tolama Yöntem Ve Araçları \& Veri Toplama Araçlarının Güvenilirlik Ve Geçerliliği. Hemşirelikte Araştırma Süreç, Uygulama ve Kritik. İstanbul: Nobel Tip Kitapevleri 2014:222-31. 